Fecha de recepción: abril 2019

Fecha de aceptación: octubre 2019

Versión final: mayo 2020

\section{La integración del cine expandido al espacio museístico}

\author{
Camila Sabeckis ${ }^{\star}$ y Eleonora Vallazza ${ }^{\star *}$
}

Resumen: En las últimas décadas la presencia de obras de cine expandido, o lo que originalmente se conoció como video arte, ha dejado de ser una excepción en las muestras y exposiciones artísticas montadas en los museos, galerías de arte y espacios dedicados a la exhibición de producciones culturales. En la actualidad en las exposiciones artísticas, ya sean sobre un autor específico o un tema elegido por un curador o la institución que lo contrata, la inclusión de obras de cine expandido ha pasado a ser casi obligatoria, e incluso en muchos casos hay muestras armadas exclusivamente a partir de la utilización del recurso audiovisual para transmitir el mensaje que el curador o el artista desean hacer llegar al público.

En las páginas siguientes desarrollaremos cuatro ejemplos de este tipo de exhibiciones que han tenido lugar en Buenos Aires, Argentina, entre 2015 y 2017, que dan cuenta de este fenómeno cada vez más habitual que es la inclusión de material visual o audiovisual en los espacios dedicados a exposiciones artísticas, dos de los ejemplos refieren a muestras en las que las producciones de cine expandido forman parte de un conjunto de obras de distintos formatos, y los otros dos son muestras montadas exclusivamente con obras audiovisuales. También plantearemos antecedentes que, dentro del campo cultural argentino, han marcado un cambio en la perspectiva de montaje y curaduría de muestras, al incorporar imagen electrónica y pantallas.

De esta manera el cine expandido hace honor a su nombre expandiéndose cada vez más hasta convertirse en una presencia imprescindible en el ámbito de las exposiciones artísticas y culturales.

Palabras clave: Cine expandido - Museos - Exhibición - Imagen electrónica.

[Resúmenes en inglés y portugués en la página 224]

${ }^{(*)}$ Licenciada y Profesora en Artes, Especialización Artes Combinadas, colaboró como asistente de investigación en el Instituto de Historia del Arte Latinoamericano y Argentino, Facultad de Filosofía y Letras de la Univerisad de Buenos Aires. Las tareas desempeñadas fueron las siguientes: redacción de trabajos críticos y monográficos, colaboración en la organización de jornadas y congresos internacionales del GETEA (Grupo de Estudios de Teatro Argentino e Iberoamericano) durante los años 2000-2002. En los últimos años se dedicó a las tutorías de proyectos de graduación. Actualmente se desempeña como tutora del Proyecto de Graduación de Lucila María Sanguinetti, alumna de la Carrera de Licenciatura en Comunicación Audiovisual de la Universidad de Palermo. Título: El espejo resquebrajado, El metacine y sus características. 
${ }^{(*)}$ Máximo título académico obtenido: Especialista Superior en Gestión Cutltural (Fundación Konex) Licenciada y Profesora en Artes (FFyL-UBA). Cargo docente: Adjunta. UADE y UP (Argentina). Investigadora categorizada: $n^{\circ}$ 5. En el mismo año como integrante del Programa de Investigación de la Facultad de Diseño y Comunicación de Universidad de Palermo, presentó en el $2^{\circ}$ Congreso Latinoamericano de Enseñanza del Diseño el proyecto de investigación 2011: "El Found Footage como práctica del video-arte argentino de la última década". Coordinó la publicación " 50 de años de soledad: aspectos y reflexiones sobre el universo del video arte” en el cual publicó el prólogo y el ensayo El video arte y la ausencia de un campo cultural específico como respuesta a su hibridación artística [Cuaderno No 52 UP]. En vinculación directa con la temática planteada publicó Nuevas tecnologías, arte y activismo político [Cuaderno No45 UP].

\section{Antecedentes del cine expandido integrado a muestras de arte}

En el presente ensayo, realizaremos un recorte espacial al campo cultural argentino y a su circuito de exhibición de obras en museos y espacios culturales de la ciudad de Buenos Aires. Si bien, el eje de la reflexión, se centra en muestras de los últimos años, resulta pertinente mencionar antecedentes.

Cuando pensamos en vanguardias y en modos alternativos de exponer o de montar obras de arte, desde una perspectiva histórica, miramos inmediatamente aquellas experiencias propiciadas a fines de la década del sesenta dentro del marco de las actividades del Instituto Di Tella. Un claro ejemplo de muestra-instalación que incorpora la imagen electrónica a través de pantallas de televisión, fue la desarrollada por Marta Minujín a través de su obra La Menesunda. Se caracterizó por su estructura laberíntica que Minujín y Rubén Santantonín construyeron en el Instituto Torcuato Di Tella con la colaboración de los artistas Floreal Amor, David Lamelas, Leopoldo Maler, Rodolfo Prayón y Pablo Suárez: organizada a partir de una secuencia de espacios ambientados con muy diversos materiales y dispositivos que generaban estímulos sensoriales en el visitante, la obra ocupaba unos 400 metros cuadrados.

La Menesunda fue una de las exposiciones, según Marta Minujín que en esos años sesenta convocaron una cantidad inédita de visitantes (y aquí hay que señalar que la exhibición de arte cinético del Groupe de Recherche d'Art Visuel realizada un año antes en el Museo Nacional de Bellas Artes también tuvo una convocatoria formidable: 50.000 visitantes en 1964 contra los 30.000 durante los quince días de La Menesunda) (Plante, 2015).

Esta ambientación que Marta Minujín y Rubén Santantonín presentaron en el Instituto Di Tella en mayo de 1965 incluyó el primer circuito cerrado de televisión de la historia del arte. Ese circuito cerrado estaba ubicado entre monitores que transmitían la programación habitual: el visitante era confrontado así con su propia imagen formando parte del discurso fragmentado de la televisión. 
Según el investigador Rodrigo Alonso, los antecedentes de los vínculos entra el arte y la tecnología, también pueden ampliarse al concepto desarrollado por el presente ensayo, el de "cine expandido", ubicándonos en la década del sesenta en Argentina. El autor, en principio realiza una contextualización de los medios de comunicación masivos y su relación con el entorno cotidiano. Plantea que en los sesenta la penetración de la televisión en los hogares estaba redefiniendo las relaciones del público con la imagen en movimiento. Es aquí en donde los espacios culturales como museos o centros culturales cobran un lugar fundamental a la hora de poner en crisis esta relación demostrando las tensiones entre el medio televisivo y los relatos construidos por el mismo. Se produce así la deconstrucción de esa situación en museos y galerías de arte. "Influenciados por el pop art y el conceptualismo, algunos artistas comenzaron a experimentar con el uso de filmes en el espacio" (Alonso, 2005).

Alonso señala también que en 1966, inspirada en la cultura hippie y las teorías sobre los medios de comunicación masiva del filósofo estadounidense Marshall McLuham, "Marta Minujín comienza una serie de obras que exaltan la mediatización de la experiencia cotidiana, sumergiendo al espectador en el universo visual e hiper-fragmentado de los mass media" (Alonso 2005). La primera de esas obras fue Simultaneidad en Simultaneidad presentada aquel año en el Instituto Di Tella de Buenos Aires. Para su realización, Minujín convocó a 60 invitados que fueron filmados, fotografiados y entrevistados, antes de ocupar un lugar frente a un televisor, que debían mirar al mismo tiempo que escuchaban un receptor radial. Once días más tarde, las mismas personas ubicadas en los mismos lugares vieron proyectadas en las paredes las fotografías y filmes tomados el primer día, escucharon sus entrevistas en los altoparlantes de la sala, observaron en los televisores las imágenes de la primera jornada y escucharon en las radios un programa especial referido al suceso. En 1967 Minujín realiza otra experiencia denominada Circuit en la Expo '67 de Montreal; una ambientación más compleja pero que sigue privilegiando los aspectos sensoriales de los medios.

Los participantes fueron elegidos por una computadora que seleccionó personas con características similares a partir de encuestas publicadas en un periódico. La ambientación incorporaba algunos datos de los participantes, mientras circuitos cerrados de televisión permitían a algunos grupos observar el comportamiento del resto (Alonso 2005).

Otra experiencia de la artista que explora las relaciones de los medios de comunicación a través de la imagen electrónica con el público fue Minucode (New York, 1968). Aquí, Marta Minujín realizó tres cócteles con diferentes grupos de personas -empresarios, personalidades de los medios y artistas- que eran registrados con una cámara cinematográfica oculta. Los registros fueron proyectados en las paredes de una sala a la que se invitaba luego a los mismos participantes a concurrir. En la situación final, cada participante interactuaba no sólo con las imágenes de los diferentes grupos sino también con sus integrantes. Continuando con los antecedentes artísticos de la década del sesenta y setenta en Argentina, que integra la imagen electrónica como también el cine expandido a espacios museísticos, podemos mencionar obras de diversos artistas. En 1967 Oscar Bony, presentó 
60 Metros Cuadrados de Alambre Tejido y su Información, una instalación formada por la cantidad de alambre mencionada en el título, dispuesta sobre el piso de una sala, y un proyector que exhibía un fragmento del mismo alambre sobre la pared. En 1971 Leopoldo Maler realizó En Silencio, en esta obra, la imagen de una enferma reemplazaba a la enferma real que era proyectada sobre la cama que una enfermera vigilaba. La obra articulaba una performance con lo que hoy consideraríamos una video instalación, debido a la ubicación horizontal de la imagen, extraña a la proyección cinematográfica habitual. También en 1971 Lea Lublin utilizó proyecciones cinematográficas en Dentro y Fuera del Museo, una obra que buscaba instaurar un diálogo entre los acontecimientos políticos, sociales y culturales, y el desarrollo artístico concomitante. Para esto, Lublin instaló pantallas que proyectaban documentales sobre arte frente a un museo y ubicó en su interior diagramas que comparaban acontecimientos históricos destacados con el desarrollo artístico del mismo período. Por otro lado David Lamelas utilizó en 1972 la imagen cinematográfica para analizar un espacio y el propio modelo narrativo del cine en Film Script:

Un cortometraje exhibía las acciones de una empleada de la galería, mientras tres proyectores de diapositivas variaban la secuencia narrativa del film: el primero, siguiendo la continuidad con fotos fijas seleccionadas; el segundo, modificando el orden de dos escenas; el tercero, dejando los momentos más importantes y eliminando una de las escenas. De esta manera, el film se confrontaba con las acciones que efectivamente realizaba la empleada durante la exhibición y con su propia lógica narrativa (Alonso, 2005).

Durante las décadas mencionadas la imagen electrónica también comienza a ser trabajada como parte fundamental de una muestra artística. Uno de los primeros casos fue en 1966 con Simultaneidad en Simultaneidad. En 1967 David Lamelas presentó Situación de Tiempo una sala iluminada por diecisiete televisores que transmitían ruido de señal y sonidos vagos. La instalación llamaba la atención sobre la naturaleza temporal del medio electrónico. Esta obra se relacionó con otra de 1968, donde Lamelas dispuso en una sala dos proyectores de diapositivas que sólo proyectaban luz, condición de posibilidad de la imagen cinematográfica.

En 1969, otras dos piezas volvían a utilizar la imagen electrónica: Especta, del Grupo Frontera y Fluvio Subtunal de Lea Lublin. La primera era una experiencia comunicacional formada por un mini-estudio de grabación y seis televisores. Los espectadores respondían una pregunta mientras eran registrados en video; al salir, podían ver su respuesta en los monitores junto con la concurrencia del lugar. Fluvio Subtunal era un recorrido en nueve “zonas". Una de ellas, la "zona tecnológica”, incluía quince televisores en circuito cerrado mostrando lo que ocurría en las restantes.

\section{El cine expandido como parte de una muestra artística en la actualidad}

A continuación describiremos dos exhibiciones recientes en las cuales el cine expandido ha formado parte importante del montaje de las mismas. 
En el presente año, 2017, dos muestras muy diferentes entre sí, por el tema y la intención del curador a la hora de diseñarlas, y por los espacios culturales donde fueron montadas, tuvieron lugar en la ciudad de Buenos Aires. La primera, "El CCK en movimiento", una muestra de carácter local, curada por el argentino Rodrigo Alonso y realizada en el mes de Febrero en el Centro Cultural Kirchner, ubicado en pleno centro de la ciudad (espacio que hasta el año 2015 fuera la sede del correo central, que ha sido remodelada especialmente para cumplir la función de Centro Cultural). La segunda una muestra internacional: "Sublevaciones", curada por el historiador de arte francés Didí Huberman, presentada entre los meses de Junio y Agosto en el Museo de los inmigrantes, (lugar que en el siglo XIX había sido un hotel para inmigrantes y conserva aún la impronta del espacio original), perteneciente a la Universidad Nacional de Tres de Febrero, que si bien está ubicado cerca del centro de la ciudad el acceso a este espacio es menos directo que al Centro Cultural Kirchner, lo que podría presuponer que los públicos que concurrieran a ambas exposiciones fueran diferentes, teniendo en cuenta además la diferencia de las temáticas propuestas en ellas. Ambos espacios tenían en común el hecho de pertenecer al ámbito público, es decir, no eran instituciones privadas.

Dos muestras muy disímiles entre sí, como puede deducirse de lo expuesto, presentadas en espacios prácticamente antagónicos, pero que tenían en común la inclusión de varias piezas de video arte en su recorrido, las cuales poseían además una presencia destacada dentro del diseño de la exposición, es decir no eran una excepción dentro del montaje de la misma sino que tenían un lugar relevante, tanto en lo referente al espacio físico que ocupaban, como a su ubicación en el recorrido de la muestra y a la importancia de su presencia para el mensaje que el curador buscaba transmitir.

\section{El CCK en movimiento}

Como mencionamos anteriormente la muestra tuvo lugar en el mes de febrero en el Centro Cultural Kirchner, y fue realizada por Rodrigo Alonso, destacado curador argentino, con una amplia experiencia curatorial internacional, quien además ha escrito una serie de ensayos sobre arte y nuevas tecnologías, e incluso ha investigado el tema del video arte y tiene varios artículos escritos sobre esta cuestión. Alonso fue contratado especialmente por el gobierno de la ciudad de Buenos Aires como curador para que diseñara una exhibición que se presentaría en las salas del segundo piso del Centro Cultural mencionado como dijimos, en Febrero de 2017, época de receso de verano y poca concurrencia de público a este tipo de espacios.

La exposición diseñada por Alonso estaba pensada a partir del tema de la "performance", por eso la palabra "movimiento" del título de la misma, y se caracterizaba, al igual que la de Didí Huberman, por la diversidad estética de las obras presentadas: fotografías, videoinstalaciones, performances en vivo y otras filmadas, a cargo de distintos autores provenientes de las artes escénicas y visuales, e incluso en el marco de la muestra, que duró ocho días (se presentó entre el 11 y el 26 de febrero de jueves a domingos), se ofrecieron además una serie de charlas y conferencias a cargo de diversos artistas, curadores e intelectuales, en relación con las nuevas miradas sobre las temáticas presentadas en la exposición, cuyo eje central era el mismo que el de la exhibición, la performance. 
$\mathrm{Al}$ respecto de la propuesta, en una nota escrita en el diario Página 12 su curador decía lo siguiente:

La muestra pone de manifiesto la importancia que posee la acción como método para la creación o motivo, en buena parte de la producción artística argentina reciente. Incluye obras procedentes de diferentes disciplinas, elaboradas en espacios públicos y privados, cuidadosamente diseñadas y espontáneas, realizadas con procedimientos sofisticados y amateurs, pertenecientes a artistas consagrados y emergentes. En conjunto, ofrece un sucinto panorama de esta singular tendencia del arte argentino contemporáneo, con el fin de evidenciar su vitalidad y complejidad actual (Alonso, 2017).

Organizada en distintos núcleos temáticos, en la muestra podían verse obras realizadas tanto en espacios públicos como privados; algunas hechas con especial cuidado y detalle y otras más espontáneas. Temas como los viajes, la intimidad, la palabra, los vínculos y la figura de lo masculino estaban presentes en las distintas obras que formaron parte de la exhibición.

En su crítica de la muestra el diario La Nación en una nota del 13 de Febrero de 2017 decía lo siguiente:

Para el curador, la exposición evidencia la importancia de la acción como método para la creación o impulso de buena parte de la producción artística local reciente. La muestra incluye desde acciones con anclaje en experiencias personales hasta planteos conceptuales (Oybin).

Debido a los límites de extensión del presente ensayo, hemos decido realizar una selección de piezas de las muestras analizadas para ejemplificar el tema desarrollado, entre ellas podemos destacar las siguientes:

Burbujas (2003) de Karina Peisajovich: consistía en una obra audiovisual en la que se veía a una mujer con una peluca roja vestida con círculos rojos que se asemejaban a globos, que luego explotaban provocando un fuerte sonido muy similar al ruido de un disparo, el vestido iba desapareciendo pero no se mostraba el cuerpo de la mujer sino un vacío gradual, de esta forma el cuerpo era construido partir de una serie de globos separados entre sí. Por su parte, Gabriela Golder, artista y curadora Argentina que se destaca por su producción en el ámbito del video experimental monocanal y de las instalaciones audiovisuales, presentó su obra Conversation Peace (2012) una video instalación, que fue montada en tres pantallas gigantes, una al lado de la otra, en las cuales veíamos y escuchábamos a dos niñas leyendo El Capital de Carl Marx bajo la atenta supervisión de su abuela. El espectador se encontraba con la video instalación ni bien entraba en la sala, en la pantalla que estaba frente a él a la izquierda se veía un plano medio de la abuela sentada leyendo un libro, en la del medio la toma se abría, transformándose en un plano general, para mostrarnos la habitación donde ocurría la acción, veíamos entonces a la abuela en un sillón leyendo y en diagonal a ella sentadas en otro sillón de estilo antiguo dos niñas leyendo un libro cada una, en la tercera pantalla el plano volvía a acercarse y tomaba a las niñas en un plano 
medio. De esta forma la artista mostraba una misma acción dividida en tres pantallas, el video presentaba así el proceso de aprendizaje como algo misterioso y fascinante.

Otra de las piezas de video arte destacadas fue la video performance de la artista Ananké Assef, Constelaciones (2010): en un espacio cerrado había diez personas de distintos sexos y edades paradas, la artista era una de ellas, el lugar comenzaba a llenarse de agua que ingresaba al reducto a presión a través de varios chorros de agua, mientras se observaban variaciones de viento e iluminación. Quienes participaban de la performance ignoraban cuánto iba a durar la acción y cuál era el límite de subida del agua que poco a poco llenaba el reducto. La consigna de la performance era "resistir". El video duraba en total 25 minutos. Los participantes se veían impasibles frente a la situación, no evidenciando en sus expresiones en ningún momento algún tipo de temor, preocupación o incomodidad por la situación a la que estaban expuestos, mientras que la tensión del espectador crecía a medida que observaba como el agua iba subiendo y tapando los cuerpos.

Sistema de caminos (2009), es otra de las obras que consideramos importante destacar, consistía en una video instalación conformada por pantallas de diferentes tamaños y formatos, algunas ubicadas en el piso, otras colgadas de las paredes, en las que se reproducían distintos momentos de un video de la artista Florencia Levy, en el cual veíamos el recorrido que hacían algunos de sus amigos y conocidos en sus viajes cotidianos al trabajo mientras eran filmados por Levy que los acompañaba en su trayecto, transformando así una situación rutinaria y monótona en videoarte. La artista hace en esta obra una suerte de investigación de la vida cotidiana al acompañar los recorridos de otros y registrar lo que ellos viven cada vez que se trasladan a su trabajo, tratando de ver aquello que los otros ven en su trayecto diario a bordo de un medio de transporte. El video contenía en total 16 viajes.

\section{Sublevaciones}

La muestra "Sublevaciones", como mencionamos, tuvo lugar en el Centro de Arte Contemporáneo de la UNTREF, en el ex Hotel de Inmigrantes. No era una exposición artística convencional, sino más bien un ensayo en imágenes del historiador de arte y curador Georges Didí-Huberman, uno de los filósofos franceses más relevantes de la última década, quien reflexiona respecto de que es lo que nos moviliza a sublevarnos.

Una exposición sobre los acontecimientos políticos y las emociones colectivas que conllevan movimientos de masas en lucha. La misma trata sobre los desórdenes sociales, la agitación política, la insumisión, las revueltas y las revoluciones de todo tipo, y muestra cómo los artistas han abordado estos temas en diferentes momentos históricos (Librera, 2017).

Conformada por más de 290 imágenes, la exhibición se montó por primera vez en el Museo Jeu de Paume de París (entre Octubre de 2016 y Enero de 2017), pasó por Barcelona en el mes de Mayo de 2017 y se prevé que se realice también en México y Brasil. En la exposición se mostraban grabados, xilografías, fotografías, videos, pinturas, etc. La muestra cambia de acuerdo al país en que se presenta, dado que se agregan obras que tengan que ver con el contexto histórico del mismo o de países cercanos. En el caso de la exhibición 
que se armó en Buenos Aires se agregaron 50 obras que fueron seleccionadas por la Directora de la Untref, Diana Wechsler.

El prólogo escrito por Didí Huberman, que podía leerse en una pared del Museo antes de ingresar a la muestra, resumía la idea de la que partió el curador para conformar la muestra:

¿Qué nos subleva? Una serie de fuerzas: psíquicas, corporales, sociales. Con ellas transformamos lo inmóvil en movimiento, el abatimiento en energía, la sumisión en rebeldía, la renuncia en alegría expansiva. Las insurrecciones ocurren como gestos: los brazos se levantan, los corazones palpitan más fuerte, los cuerpos se despliegan, las bocas se liberan. Las sublevaciones no llegan nunca sin pensamientos, que a menudo se convierten en frases: la gente reflexiona, se expresa, discute, canta, garabatea un mensaje, fabrica un cartel, distribuye un panfleto, escribe un libro de resistencia (2017).

Entre las 290 piezas que conformaban el ensayo en imágenes propuesto por el curador el video arte tuvo un lugar destacado, no sólo por la cantidad de obras audiovisuales que formaron parte de la muestra sino también porque el recorrido comenzaba y terminaba con una obra de videoarte, ambas realizadas por la misma artista. Apenas el espectador atravesaba la puerta que conducía a la primera sala (de las dos en que se montó la exhibición) se encontraba con un video proyectado en grandes dimensiones en una pared que dividía la sala en dos espacios. El título de la obra era Remontajes: un video de la artista griega María Kourkouta, del año 2016, en el que se veían imágenes de importantes films clásicos que tratan el tema de las sublevaciones, como La Huelga (1924) o El Acorazado Potemkim (1925) del director de cine Sergei Eisenstein, cuya obra se caracterizó por ser un cine político y de propaganda. Al final de la muestra otro video de la misma autora, esta vez reproducido en un televisor de pantalla plana, mostraba a migrantes, hombres, mujeres y niños, que caminaban por la frontera entre Grecia y Macedonia.

Además de estas obras cuyo tema estaba ligado ineludiblemente a sublevaciones relacionadas con lo político social, la muestra incluyó otros videos que trataban el tema de la sublevación de forma más abstracta, que consistían en perfomances cuya acción implicaba una sublevación individual sin relación alguna con el tema político que impregnaba en general el eje de la muestra. Era el caso de un video de Claude Catellain, denominado 46 (2009) que se proyectaba en un televisor de pantalla plana en una pared en perpendicular a la que en el ingreso mostraba los fragmentos de films. En el video veíamos a un hombre en una habitación vacía, quien durante poco más de seis minutos intentaba permanecer sentado en una silla, mientras la levantaba pretendiendo poner debajo de sus patas delanteras una serie de bloques de madera para que la silla quedara apoyada sobre estos en posición inclinada. El video era reproducido continuamente sin sonido, para poder escucharlo era necesario colocarse unos auriculares ubicados al costado del televisor que permitían oír los sonidos que producía la perfomance, el video no tenía música ni ruidos ajenos a la acción filmada.

Otro video que podemos destacar de la muestra es Un vaso de leche (1972), de Jack Goldstein, que era proyectado sobre una pared al fondo de la sala, el sonido producido por 
esta obra, (un golpe continuo contra una mesa) se escuchaba constantemente desde que entrabamos al espacio de exhibición, aunque hasta que no avanzábamos en el recorrido no podíamos saber de qué se trataba, ya que la obra no estaba visible al ingresar debido a que la sala se encontraba divida en secciones por varios paneles, de los que colgaban obras de diversos formatos. El video realizado en blanco y negro muestra sólo una mesa con un vaso con leche, y en el extremo de la misma un puño que golpea constantemente la mesa provocando el derrame del contenido con cada golpe y que el vaso se vaya moviendo cada vez más hacia el borde hasta terminar cayendo al piso.

También nos parece interesante mencionar un video denominado Conde Ferreira (2003), de Paulo Abreu, el cual mostraba una habitación con una ventana, en la que había un par de placares y una cajonera contra las paredes, en el centro de la pieza, con la ventana a sus espaldas, un joven con rastas vestido sólo con pantalones saltaba y se sacudía constantemente en el aire, sin llegar nunca a tocar el suelo. A medida que el video avanzaba la imagen filmada se iba alejando haciéndose cada vez más pequeña hasta desaparecer. Una música estridente al ritmo de los movimientos del joven sonaba de fondo durante el minuto y medio que duraba el video, que es en realidad una performance filmada que presenta unos saltos de capoeira que editados semejan un estado de exasperada levitación. Deja a la imaginación del espectador elaborar un significado de lo que se ve en el video, que bien podría asociarse a un estado de locura o exasperación.

Los ejemplos desarrollados son sólo una pequeña reseña de lo que podía verse en "Sublevaciones", una muestra en la cual como dijimos muchas de las 290 piezas expuestas eran de carácter audiovisual.

\section{Muestras de cine expandido}

\section{Clamor 2015, Andrés Denegri}

La muestra fue presentada en el Centro Cultural Recoleta en Buenos Aires en Agosto de 2015, un centro de exposiciones ubicado en la zona norte de la Ciudad, que se caracteriza por su innovación a la hora de presentar exposiciones y actividades culturales. Un lugar clave dentro del circuito del arte en la ciudad de Buenos Aires. Clamor era una instalación de Andrés Denegri, un realizador independiente de cine, video y TV, interesado en la experimentación visual y narrativa. La instalación, de considerables dimensiones, estaba conformada por tres obras: Éramos esperados (2012), Éramos esperados (16mm) (2013) y Éramos esperados (35mm) (2015) cada una de las cuales consistía en dos películas proyectándose constantemente: una de las primeras de la historia del cine filmada por Lumière y una de las primeras realizadas en nuestro país, del argentino Eugenio Py.

$\mathrm{Al}$ entrar a la sala vemos que está invadida por las máquinas, por proyectores de cine, montados en andamios, metros y metros de película, pantallas que interceptan imágenes de las cintas que se mezclan y entrecruzan. Todo está interceptado por todo. Cada cosa u objeto es soporte, es contenido, a la par que 
interviene el resto de los soportes y contenidos generando una multiplicidad de posibles enfoques según el ángulo desde donde cada público haga foco en las partes. Las cintas de película se ven delante de la propia imagen que proyectan esas mismas cintas, por ejemplo (Rizzo, 2015).

Las tres obras que integraban Clamor consistían en dos proyectores de cine enfrentados que emitían cada uno las mismas imágenes que eran capturadas por una pantalla que se encontraba entre ellos. Una de las proyecciones mostraba el corto Obreros saliendo de la fábrica (1895), de Louis Lumière; una de las primeras películas filmadas en la historia del cine, un documental en el que vemos a unos obreros saliendo de su trabajo. La otra proyección exhibía La bandera argentina, (1897) de Eugenio Py, la primera filmación realizada en nuestro país (Argentina) que consiste en la imagen de una bandera flameando. Las únicas diferencias entre las tres obras que conformaban la videoinstalación era el soporte cinematográfico de los films proyectados, así como también los proyectores correspondientes, las estructuras con las que se sostenían estos proyectores y sus tamaños.

La obra propiciaba la participación del espectador, ya que para que se accionara el mecanismo de reproducción de imágenes, este debía meterse dentro de la estructura y caminar entre los equipos que proyectaban las imágenes, porque los proyectores contaban con sensores que accionaban la maquinaria al moverse el visitante, razón por la cual el espectador debía implicarse en la obra y no solamente contemplarla. De esta manera Clamor cumple con una de las características más distintivas del cine expandido, que es que el espectador no sea pasivo, sino que sea interpelado por la obra. La denominación de las obras Éramos esperados podría asociarse a este hecho de la necesidad activa del espectador para que la obra funcione, ya que sin espectador la maquinaria que permite que las proyecciones comiencen no funciona, por lo tanto no hay obra.

Cada obra hace eso, invita al espectador a participar, a involucrarse y a comprender. Porque cada obra a la vez es un recurso pedagógico, que enseña tanto a nivel técnico como artístico, para comprender a la vez: la producción de una obra de arte, la producción audiovisual y el funcionamiento del cine. De un cine que ya no es, de ese cine que puede también ser pieza de museo si no funciona, si no es verbo en movimiento (Vázquez, 2015).

\section{Operación Fracaso y el Sonido Recobrado 2015, de Albertina Carri}

Esta muestra fue la primera experiencia expositiva de Albertina Carri, una de las directoras más representativas del cine argentino contemporáneo y fue exhibida en el Parque de la Memoria, un espacio público ubicado frente al Río de la Plata en la Ciudad de Buenos Aires, que fue construido para recordar a las víctimas del golpe militar que tuvo lugar en Argentina entre 1976 y 1983. El Parque fue inaugurado en el año 2001. La instalación audiovisual de Carri, compuesta por cuatro obras, fue montada en la sala PAyS que está dentro del Parque, un espacio de gran magnitud, donde se realizan exposiciones de artes visuales, seminarios, conferencias, talleres, etc. que apuntan a reflexionar sobre el terrorismo de Estado y sus implicancias en nuestra sociedad. 
La muestra de Albertina Carri se presentó entre los meses de Septiembre y Noviembre de 2015. En el camino que llevaba al acceso a la sala se encuentra el Monumento a las Víctimas del Terrorismo de Estado, en cuyas paredes están escritos los nombres de miles de víctimas desaparecidas y asesinadas durante la última dictadura militar argentina.

En el catálogo de la muestra la artista se pregunta si es posible vivir sin recordar, a lo cual ella misma responde:

Los ríos de la memoria no siempre son caudalosos, pero aunque corra una pequeña línea de agua por su lecho, ella es tan obstinada, que modificará la tierra por la que pasa, aunque tan solo sea por el paso del tiempo mismo. Quiero ser ese lecho, quiero ser esa tierra, quiero contarle al mundo sobre ese poder que tiene el hecho de estar acá y seguir recordando (Carri, 2015).

Operación fracaso y el sonido recobrado estaba conformada por cuatro espacios en los que podían verse diferentes instalaciones visuales y sonoras: Allegro y A piacere, El punto impropio, Cine puro y La investigación del cuatrerismo, que ocupaban distintos sectores de la sala.

- Cine puro: dentro de una especie de cueva gigante hecha de rollos de celuloide, se proyectaban imágenes de un rollo de película que había quedado olvidado en un galpón, lo que podía verse eran manchas, rastros de lo que originalmente fue filmado y que el paso del tiempo ha ido borrando.

- Investigación de cuatrerismo: consistía en una video instalación a través de la cual se relataba la investigación de la artista sobre una película desaparecida basada en un ensayo titulado Isidro Velázquez: formas prerrevolucionarias de la violencia (1968), escrito por su padre Roberto Carri, y filmada por el cineasta Pablo Szir, antes de su desaparición forzada. La video instalación constaba de cinco pantallas en donde se proyectaban imágenes cinematográficas envejecidas como por ejemplo fragmentos blanco y negro de películas de los años 40 casi veladas y noticieros con lluvia de los años setenta que contaban las operaciones de la guerrilla.

- A piacere y Allegro eran dos instalaciones sonoras, que compartían un mismo espacio, detrás de estas, en la pared del fondo de la sala estaba escrita en letras gigantes la palabra "presente". En A piacere, el espectador debía encender unos viejos proyectores que producían ciertos sonidos que Albertina Carri asociaba con lo que se vivencia dentro del vientre materno. Allegro constaba de máquinas de proyectar sin películas, de forma que el espectador escuchara el sonido del cine, sin la presencia de cinta. Aunque estas obras no pueden incluirse dentro de lo que denominamos cine expandido, porque no proyectaban imágenes, consideramos necesario mencionarlas por el hecho de que los proyectores que componen la instalación remiten a la esencia misma del cine.

- Punto impropio: era una video instalación en la cual se podían escuchar, en la voz de Albertina Carri, fragmentos de las cartas que su madre le enviara a ella y sus hermanas estando detenida. En una sala casi a oscuras veíamos proyectadas una serie de imágenes 
en loop, figuras de distintos colores y formas que se repiten una y otra vez, y en el piso la proyección de una imagen en la que estaba escrito el nombre Ana María, que es como se llamaba la madre de Albertina Carri, entre medio de los dos nombres, había una imagen circular en tonos blancos y azules que eran las cartas filmadas a través de un microscopio, una especie de textura conformada por tinta y papel. Las cartas hablaban de la vida cotidiana de Albertina y sus hermanas en el momento en que su madre estaba cautiva, en ellas le preguntaba a sus hijas respecto de situaciones que vivían a diario y les daba consejos sobre cómo proseguir con sus vidas.

Carri vuelve sobre temas ya trabajados en obras anteriores, relacionados con la desaparición de sus padres durante la última Dictadura militar Argentina. Ficción y realidad se entrecruzan para reconstruir la memoria sobre los desaparecidos. La muestra era una suerte de autobiografía de la artista, en la que recordaba a sus padres, a la vez que volvía a hacer presente un período trágico del pasado de nuestro país.

Para armar las instalaciones la artista recopiló documentos, cartas, publicaciones, fragmentos fílmicos, guiones, etc. que permiten recuperar la memoria de ese momento tan traumático que fue la Dictadura de 1976 en Argentina y que a Carri le tocó vivir muy de cerca. La obra hablaba de su historia personal pero remitía también a nuestra historia como argentinos.

\section{Reflexiones finales}

A partir de lo desarrollado creemos que es posible hablar del cine expandido como una modalidad artística, que habiendo surgido como algo experimental y marginal en los años sesenta, en la actualidad ha sido incorporada de manera casi excluyente en las exhibiciones artísticas que se presentan en Museos y espacios dedicados a muestras Culturales. Como hemos podido apreciar en los ejemplos descriptos, los curadores hoy eligen este tipo de obras realizadas en formato audiovisual para incluirlas en exhibiciones en las que también pueden verse expresiones artísticas de todo tipo: pintura, fotografía, escultura, performance, etc., eligiéndolas siempre en relación con la temática que guía la exposición, sin importar si se trata de un recorrido por la producción artística de un autor, como puede ser una muestra sobre un pintor, un fotógrafo, o un escritor específico, por ejemplo, o de una exhibición que plantea dar cuenta de un tema determinado, como era el movimiento como creación en el caso del trabajo diseñado por Rodrigo Alonso o de aquello que nos mueve a sublevarnos, en el ensayo en imágenes de Didí Huberman. Asimismo hemos visto como incluso el cine expandido ha terminado por conformar muestras artísticas en sí mismas como es el caso de las obras de Andrés Denegri y Albertina Carri, que no formaban parte de una muestra más amplia en la que se presentaban obras realizadas en otro formato, sino que eran exhibiciones de obras realizadas en formato audiovisual cuyas características: multiplicidad de pantallas, proyecciones simultáneas, participación activa del espectador, no linealidad del relato fílmico, proyecciones en pantallas de gran formato o paredes, etc. son algunas de las que predominan en lo que Gene Youngblood en su libro del año 1970 denominó cine expandido, un nuevo cine que se aleja del formato clásico y sale del espacio de la sala oscura para expandir sus fronteras más allá e involucrar al es- 
pectador de manera activa en la obra, sacándolo de su pasividad, proponiéndole pensar y otorgarle un significado a las imágenes que tiene frente a él.

\section{Bibliografía}

\section{Libros}

Youngblood, G. (2013). El cine expandido. Buenos Aires, Eduntref.

\section{Publicaciones en línea}

Alonso, R. (14 de Febrero de 2017). Con una marcada tendencia a la acción. Buenos Aires. Página 12. Disponible en: https://www.pagina12.com.ar/20048-con-una-marcadatendencia-a-la-accion

Alonso, R. (2005). Arte y tecnología en Argentina: los primeros años. Disponible en: http:// www.roalonso.net/es/arte_y_tec/primeros_anios.php

Altilio, P. (2 de Marzo de 2017). Nueve maneras de ser público y artista. Buenos Aires. Revista

N. Disponible en: https://www.clarin.com/revista-enie/arte/maneras-publico-artista _0_SJPVJMU9x.html

Carri, A. (2015). Operación fracaso y el sonido recobrado. Catálogo de la muestra. Buenos Aires. Parque Nacional de la memoria. Disponible en: https://issuu.com/parquedelamemo ria/docs/catalogo_albertinacarri_final_simpl

Librera, J. (20/06/2017). Sublevaciones de Didi Huberman en argentina. Disponible en: https:// juanpablolibrera.com/2017/06/20/sublevaciones-de-didi-huberman-en-argentina/

Los Inrockuptibles (17 de Noviembre de 2015) Muestras: "Operación fracaso y el sonido recobrado", de Albertina Carri, Buenos Aires. Disponible en: https://losinrocks.com/muestrasoperaci\%C3\%B3n-fracaso-y-el-sonido-recobrado-de-albertina-carri-1819d91317ee

Oybin, M. (13 de Febrero de 2017). Arte en movimiento en el CCK. La Nación. Disponible en: http://www.lanacion.com.ar/1983874-en-verano-performance-de-todos-y-paratodos-en-el-cck

Plante, I. (2015). La Menesunda según Marta Minujín. Disponible en: https://www.unsam. edu.ar/ojs/index.php/tarea/article/download/158/149

Rizzo, N. (2015). El 'Clamor' de los que 'Eramos Esperados', entrevista a Andrés Denegri Disponible en: http://www.laizquierdadiario.com/El-Clamor-de-los-que-Eramos-Esperados -entrevista-a-Andres-Denegri

Vázquez, M. (10 de Noviembre de 2015). La voz pasiva de las máquinas de imágenes. Reseña sobre la obra de Andrés Denegri: Clamor. Buenos Aires, Revista Lindes. Disponible en: http://www.revistalindes.com.ar/contenido/numero10/nro10_ins_VAZQUEZ.pdf

\section{Videos}

Abreu, P. (2003). Conde Ferreyra. Disponible en: https://vimeo.com > paulo abreu > Videos. Assef, A. (2010). Constelaciones. Disponible en: https://www.anankeasseff.com/constelaciones. Cattelain, C. (2009). 46. Disponible en: https://www.youtube.com/watch?v=XVf_rM3Fv1o Golder, G. (2012). Conversation piece. Disponible en: https://vimeo.com > Gabriela Golder , Videos. 
Goldstein, J. (1972). Un vaso de leche. Disponible en: https://vimeo.com > Voir \& Dire > Videos (Extracto).

\begin{abstract}
In recent decades the presence of expanded cinema works, or what was originally known as video art, is not any longer an exception in the art exhibitions in museums, art galleries and exhibition spaces. Today in the art exhibitions, either about a specific author or a theme chosen by a curator or the institution that hired him, the inclusion of works of expanded cinema has become almost mandatory, and even in many cases there are exhibitions armed exclusively from the utilization of the audiovisual. On the following pages we will develop four examples of this type of exhibition that took place in Buenos Aires, Argentina, between 2015 and 2017.
\end{abstract}

Keywords: Expanded cinema - Museum - Exhibition - Electronic Image.

Resumo: Nas últimas décadas, a presença de obras cinematográficas ampliadas, ou o que era originalmente conhecido como videoarte, deixou de ser uma exceção nas exposições e exposições de arte montadas em museus, galerias de arte e espaços dedicados à exibição de produções cultural. Atualmente em exposições artísticas, seja sobre um autor específico ou um tema escolhido por um curador ou a instituição que o contrata, a inclusão de obras de cinema expandido tornou-se quase obrigatória, e mesmo em muitos casos há amostras armadas exclusivamente do uso do recurso audiovisual para transmitir a mensagem que o curador ou o artista deseja transmitir ao público. Nas páginas seguintes, desenvolveremos quatro exemplos deste tipo de exposições que aconteceram em Buenos Aires, Argentina, entre 2015 e 2017, que representam esse fenômeno cada vez mais comum que é a inclusão de material visual ou audiovisual no espaços dedicados a exposições artísticas, dois dos exemplos referem-se a exposições em que as produções cinematográficas expandidas fazem parte de um conjunto de obras de diferentes formatos, e as outras duas são amostras montadas exclusivamente com obras audiovisuais. Também levantaremos antecedentes que, dentro do campo cultural argentino, marcaram uma mudança na perspectiva de montar e curar amostras, incorporando imagens e telas eletrônicas. Desta forma, o cinema expandido faz jus ao seu nome, expandindo-se cada vez mais até se tornar uma presença essencial no campo das exposições artísticas e cultural.

Palavras chave: Cine expandido - Museos - Exhibición - Imagen electrónica.

[Las traducciones de los abstracts fueron supervisadas por el autor de cada artículo] 